\title{
Effect of primary organic sea spray emissions on cloud condensation nuclei concentrations
}

\author{
D. M. Westervelt ${ }^{1}$, R. H. Moore ${ }^{2}$, A. Nenes ${ }^{2,3}$, and P. J. Adams ${ }^{1,4}$ \\ ${ }^{1}$ Department of Civil and Environmental Engineering, Carnegie Mellon University, Pittsburgh, PA, USA \\ ${ }^{2}$ School of Chemical and Biomolecular Engineering, Georgia Institute of Technology, Atlanta, GA, USA \\ ${ }^{3}$ School of Earth and Atmospheric Sciences, Georgia Institute of Technology, Atlanta, GA, USA \\ ${ }^{4}$ Department of Engineering and Public Policy, Carnegie Mellon University, Pittsburgh, PA, USA
}

Correspondence to: P. J. Adams (petera@andrew.cmu.edu)

Received: 8 February 2011 - Published in Atmos. Chem. Phys. Discuss.: 16 February 2011

Revised: 7 October 2011 - Accepted: 16 December 2011 - Published: 2 January 2012

\begin{abstract}
This work estimates the primary marine organic aerosol global emission source and its impact on cloud condensation nuclei (CCN) concentrations by implementing an organic sea spray source function into a series of global aerosol simulations. The source function assumes that a fraction of the sea spray emissions, depending on the local chlorophyll concentration, is organic matter in place of sea salt. Effect on $\mathrm{CCN}$ concentrations (at $0.2 \%$ supersaturation) is modeled using the Two-Moment Aerosol Sectional (TOMAS) microphysics algorithm coupled to the GISS IIprime general circulation model. The presence of organics affects $\mathrm{CCN}$ activity in competing ways: by reducing the amount of solute available in the particle and decreasing surface tension of $\mathrm{CCN}$. To model surfactant effects, surface tension depression data from seawater samples taken near the Georgia coast were applied as a function of carbon concentrations. A global marine organic aerosol emission rate of $17.7 \mathrm{Tg} \mathrm{Cyr}^{-1}$ is estimated from the simulations. Marine organics exert a localized influence on $\mathrm{CCN}(0.2 \%)$ concentrations, decreasing regional concentrations by no more than $5 \%$ and by less than $0.5 \%$ over most of the globe, assuming direct replacement of sea salt aerosol with organic aerosol. The decrease in $\mathrm{CCN}$ concentrations results from the fact that the decrease in particle solute concentration outweighs the organic surfactant effects. The low sensitivity of $\mathrm{CCN}(0.2 \%)$ to the marine organic emissions is likely due to the small compositional changes: the mass fraction of $\mathrm{OA}$ in accumulation mode aerosol increases by only $\sim 15 \%$ in a biologically active region of the Southern Ocean. To test the sensitivity to uncertainty in the sea spray emissions process, we relax the assumption that sea spray aerosol number and
\end{abstract}

mass remain fixed and instead can add to sea spray emissions rather than replace existing sea salt. In these simulations, we find that marine organic aerosol can increase $\mathrm{CCN}$ by up to $50 \%$ in the Southern Ocean and $3.7 \%$ globally during the austral summer. This vast difference in CCN impact highlights the need for further observational exploration of the sea spray aerosol emission process as well as evaluation and development of model parameterizations.

\section{Introduction}

Physical processes on the ocean surface result in formation of sea spray aerosol. Sea spray aerosol in conjunction with dimethyl sulfide (DMS) emissions from phytoplankton is thought to dominate oceanic aerosol sources. It is now recognized that the oceans are also a significant source of primary and secondary organic matter (Meskhidze and Nenes, 2006; O'Dowd et al., 2004). Meskhidze and Nenes (2006) found that cloud effective radius was reduced by $30 \%$ over a phytoplankton bloom in the Southern Ocean and attributed this decrease to marine isoprene emission and SOA formation. Although oceanic phytoplankton emit several types of volatile organic compounds (VOCs) with isoprene being the major constituent, secondary organic aerosol (SOA) derived from marine sources of isoprene is now thought to comprise less than $10 \%$ of the observed total marine organic aerosol (Arnold et al., 2009; Claeys et al., 2010; Myriokefalitakis et al., 2010; Ovadnevaite et al., 2011). Primary marine sources, however, may dominate marine organic aerosol matter (Facchini et al., 2008). Primary marine organic aerosol exists 
predominantly in the Aitken and accumulation mode with less than $5 \%$ of their mass existing at sizes greater than $1 \mu \mathrm{m}$ (O'Dowd et al., 2004). NMR spectroscopy studies show that the primary marine organic aerosol are almost entirely water insoluble (Vignati et al., 2009; Facchini et al., 2008). Relatively little is known about the specific composition of these primary organic particles. It has been postulated recently that the majority contain organic hydroxyl groups similar to those found in biogenic carbohydrates dissolved in seawater (Russell et al., 2010). Other compositions have been reported as well, with evidence pointing to the presence of a lipid species in the aerosol (Cavalli et al., 2004; Gogou et al., 1998; Tervahattu et al., 2002a, b). Many of these compounds may act as surfactants, agents which lower the surface tension of nucleating cloud droplets in the atmosphere, thereby facilitating cloud droplet activation (Facchini et al., 1999; Sorjamaa and Laaksonen, 2006).

O'Dowd et al. (2008) developed a source function for primary organic sea spray based on measurements at Mace Head, Ireland. Their empirical relationship connects organic mass fraction in the sea spray aerosol to chlorophyll- $a$ concentrations retrieved by Sea-WIFS (http://oceancolor.gsfc. nasa.gov/SeaWiFS/). The correlation coefficient between organic fraction and chlorophyll- $a$ concentrations is equal to 0.3. A similar correlation has not been observed for data in the Southern Ocean at Amsterdam Island (Claeys et al., 2008). Despite these shortcomings, the O'Dowd et al. (2008) source function remains one of a few viable options for emissions of marine organic carbon aerosol, and has been implemented in at least two large scale models of the atmosphere (Lapina et al., 2011; Vignati et al., 2010). Recently, Gantt et al. (2011) developed a multi-parameter source function and tested it in Meskhidze et al. (2011). In this function, marine organic aerosol emissions are dependent on chlorophyll- $a$ concentrations, wind speed $\left(U_{10}\right)$, and particle diameter and are fit to a logistic function. The authors tested three ocean biological activity proxies: chlorophyll- $a$, dissolved organic carbon (DOC), and particulate organic carbon (POC). Of the three, chlorophyll- $a$ performed the best. Although the use of chlorophyll- $a$ as a biological activity proxy may be problematic, it appears to be one of the best options currently available. The present study and others like it serve as a preliminary test for the O'Dowd et al. (2008) source function. Although we require more ambient datasets for a full assessment, by implementing the source function into a global model and comparing to observations, we test the applicability of the Mace Head source function for predicting OC elsewhere.

In one of the first estimates of the marine organic aerosol budget, Roelofs (2008) determined a source of up to $75 \mathrm{Tg} \mathrm{C} \mathrm{yr}^{-1}$ by scaling organic emissions to ocean DMS emissions (Roelofs, 2008). Using this ratio of organic to sulfate mass concentrations is useful for sensitivity simulations but lacks grounding in a physical relationship between oceanic biota and emissions. Other works have used variations on the O'Dowd correlation and have resulted in smaller global emissions estimates when compared to Roloefs (2008). Recently, Vignati et al. (2010) applied an updated version of the O'Dowd et al. (2008) source function into a chemical transport and aerosol microphysics

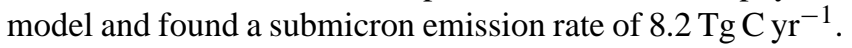
Gantt et al. (2009) estimated a submicron and supermicron source of 2.9 and $19.4 \mathrm{Tg} \mathrm{Cyr}^{-1}$, respectively, again using the O'Dowd et al. (2008) source function and chlorophyll- $a$ concentrations retrieved via remote sensing. Supermicron emissions were estimated by extrapolating the source function, which may bias the total global emissions estimate, and are not necessarily in agreement with observations (O'Dowd et al., 2004). Because sea spray exists primarily in the coarse mode, even small fractions of organic mass can result in large absolute quantities of organics in the coarse mode. In another study, Spracklen et al. (2008) used chlorophyll- $a$ concentrations to implement a diferent source function in the GLOMAP aerosol model. That work, which tuned the source function to observed organic carbon observations, found a best fit assuming a primary and secondary source of about 5.5 $\mathrm{Tg} \mathrm{Cyr}^{-1}$ in the submicron range and $2.5 \mathrm{TgC}^{-1}$ in the supermicron range. This method can provide accurate results but also lacks a physical grounding as the model results are tuned to measurements taken at a few remote locations. Using the TM4-ECPL chemical transport model with the O'Dowd correlation, Myriokefalitakis et al. (2010) found a submicron primary source of $4 \mathrm{Tg} \mathrm{Cyr}^{-1}$ and an SOA source of $1.5 \mathrm{Tg} \mathrm{Cyr}^{-1}$.

Assuming that aerosol size and composition do not change, enhancements in aerosol number and mass lead to higher cloud condensation nuclei $(\mathrm{CCN})$ concentrations. Higher amounts of CCN perturb climate by brightening clouds, which is known as the first aerosol indirect effect (Twomey, 1977). While past studies have focused mainly on mass concentrations and global aerosol budgets, this study aims to extend the analysis to determine the impact of primary marine organic matter on global and regional CCN concentrations. Fuentes et al. (2010b) studied hygroscopicty and $\mathrm{CCN}$ activity of laboratory prepared seawater samples and found a 5-24\% relative increase in the critical supersaturation for $\mathrm{CCN}$ activation in the organic-enriched samples compared to the artificial inorganic seawater. Like Fuentes et al. (2010b), our analysis explores the CCN impact through the changes in marine aerosol composition and the accompanied decreases in surface tension. We focus on the CCN activity of atmospheric organic sea spray on a global scale using atmospheric modeling, and we test the model sensitivity to separate scenarios in which marine organic carbon adds on to existing sea salt or displaces it. To do this, the combined organic-inorganic source function of sea spray developed by O'Dowd et al. (2008) is implemented into a fast and efficient global aerosol microphysics model, GISS-TOMAS. 


\section{Model description}

\subsection{GISS GCM II'}

The Goddard Institute for Space Studies General Circulation Model II-prime (GISS GCM II') was used for this modelling study. GISS GCM II' solves the three dimensional conservation equations for mass, momentum, energy, and moisture for each model grid cell. Advection of chemical species is calculated in 1-h time steps using a quadratic upstream method (Prather, 1986). The version used in this study has a spatial resolution of 4 degrees latitude by 5 degrees longitude, and a vertical resolution of 9 layers up to $10 \mathrm{mb}$ pressure. Clouds are treated with two separate parameterizations for large scale and convective clouds (Del Genio et al., 1996; Yao and Del Genio, 1999). Large-scale or stratiform clouds are assumed to be present in the simulations if relative humidity in the GCM grid cell exceeds $60 \%$. Convective clouds, which must be parameterized as a sub-grid process, are predicted based on the convective mass flux necessary to counteract the instability at cloud base (Hansen et al., 1983).

\subsection{TwO-Moment Aerosol Sectional (TOMAS) algorithm}

Aerosol microphysical calculations are done by the TwO Moment Aerosol Sectional (TOMAS) algorithm, which runs online in the GISS-GCM II' host model. TOMAS consists of codes to calculate the effects of nucleation, coagulation, condensation/evaporation, cloud processing, size-resolved dry and wet deposition, and emissions on the size distribution of aerosols at 1-h time steps (Adams and Seinfeld, 2002; Pierce et al., 2007). For this study, a faster version of TOMAS was employed to expedite computation time (Lee et al., 2011). In FAST-TOMAS, aerosol size is represented as 15 geometrically spaced size sections from $10 \mathrm{~nm}$ to $10 \mu \mathrm{m}$ in diameter. The size sections, or "bins", are spaced by average mass per particle, starting at $10^{-21} \mathrm{~kg}$ and increasing by mass quadrupling. Species treated in FAST-TOMAS include sulphate, sea-salt, hydrophilic and hydrophobic organic carbon, externally and internally mixed elemental carbon, and mineral dust. Size-resolved sulphate and mineral dust are unchanged from past studies involving GISS-TOMAS (Adams and Seinfeld, 2003; Lee and Adams, 2010). This section outlines GISS-TOMAS in its initial form whereas Sect. 2.3 describes changes made to the basic framework required to model the organic sea spray emissions.

\subsubsection{Sea spray}

Previously, GISS-TOMAS treated sea spray as consisting solely of sodium chloride. The sea spray size distribution is treated similarly to the study of Pierce and Adams (2006). The emissions parameterization used is based on Clarke et al. (2006), which relates aerosol flux to wind speed at $10 \mathrm{~m}$ altitude raised to the power of $3.41\left(U_{10}^{3.41}\right)$. The parame-
Table 1. Hygroscopicity parameters, $\kappa$, used in model.

\begin{tabular}{lc}
\hline Species & $\kappa$ \\
\hline Sea salt & 0.98 \\
Sulfate & 0.72 \\
Mineral dust & 0.03 \\
Elemental carbon & 0.02 \\
Hydrophilic OC & 0.20 \\
Hydrophobic OC & 0.09 \\
\hline
\end{tabular}

terization makes use of data observed from a coastal field campaign in order to fit the emissions flux size distribution to polynomial functions ranging from $10 \mathrm{~nm}$ to $8 \mu \mathrm{m}$ in diameter (Clarke et al., 2006). As discussed in Pierce and Adams (2006), variability in wind speed predictions in a GCM is a main source of uncertainty in the accuracy of seasalt emissions parameterizations.

\subsubsection{Organic aerosol}

Carbonaceous aerosols are configured in a similar manner to Pierce et al. (2007), with fossil fuel and biomass burning emissions specified by the Bond inventory (Bond et al., 2004). Organic aerosol is divided into four sub-categories: externally mixed EC, internally mixed EC, hydrophobic OC, and hydrophilic OC. The contributions of each of the organic categories to $\mathrm{CCN}$ activity is represented using the single, lumped, hygroscopicity parameter $(\kappa)$ of Petters and Kreidenweis (2007). Table 1 shows the values of $\kappa$ (calculated at $273 \mathrm{~K}$ ) used in our simulation. Hydrophobic OC is assigned a $\kappa$-value of 0.09 , while hydrophilic OC species are assigned a $\kappa$-value of 0.2 (see Table 1). We assume a constant OM:OC ratio of 1.8 for all emissions and for ambient organic aerosol (El-Zanan et al., 2005; Zhang et al., 2005). Previously in GISS-TOMAS, surface tension depression effects were not considered and the surface tension of pure water was applied to nucleating cloud droplets. The timescale of conversion of hydrophobic to hydrophilic aerosol was 1.5 days. Conversion from externally mixed to internally mixed EC uses this same timescale.

\subsubsection{Cloud condensation nuclei formation and scavenging}

Cloud condensation nuclei formation in the GISS-TOMAS model mimics the methods described in past model versions (Adams and Seinfeld, 2003; Pierce and Adams, 2006). Convective and stratiform clouds form at fixed supersaturations of 1.0 and $0.2 \%$, respectively. These supersaturations are then used to determine the critical diameter above which particles act as CCN. The activation diameter depends on critical supersaturation $\left(S_{\mathrm{c}}\right)$ and composition. A comprehensive form of Köhler theory is employed via look-up tables that take percent composition of sulphate, sea salt, hydrophilic 
OC, and hydrophobic OC as inputs and yield critical activation diameters at various supersaturations as output (Raymond and Pandis, 2003). When the activation diameter falls within a model size section, we interpolate linearly by using the fraction of activated particles within the section.

Wet deposition includes both in-cloud and below-cloud scavenging. For in-cloud scavenging, particles that activate to form cloud drops are removed if those cloud drops precipitate according to the GCM cloud parameterization. Belowcloud scavenging occurs when particles of any size collide with falling raindrops. A simple first-order removal scheme (Koch et al., 1999) is applied to treat below-cloud scavenging. To account for the size resolution, an updated sizedependent washout rate constant is applied as in previous model versions (Adams and Seinfeld, 2002; Dana and Hales, 1976).

\subsection{Treatment of primary marine organic aerosol}

\subsubsection{Primary marine organic source function}

Including organics in marine sea spray required several modifications to the original GISS-TOMAS framework described in the previous sections. A combined organic-inorganic sea spray source function was implemented in the form of (O’Dowd et al., 2008):

$\% \mathrm{OM}=63.015 \cdot[\mathrm{Chl}]+10$

where chlorophyll concentrations ([Chl]) are in units of $\mathrm{mg} \mathrm{m}^{-3}$ and organic matter $(\% \mathrm{OM})$ is calculated as mass fraction of the sea spray that is organic. The correlation is applied only for chlorophyll concentrations less than $1.5 \mathrm{mg} \mathrm{m}^{-3}$. Larger concentrations are assigned a maximum OM fraction of $80 \%$. The source function was applied globally to the existing sea-spray emissions parameterization in the GISS-TOMAS model, described by Clarke et al. (2006) and reviewed in Sect. 2.2.1. In one set of simulations, the total number and mass emissions of sea spray remain the same as previous versions of the model, with each particle containing a percentage OM according to Eq. (1) (simulations named "ORG"). In other words, organic aerosol mass is enhanced via the O'Dowd et al. (2008) source function by the same amount that sea-salt mass is reduced. In another simulation, instead of replacing the sea salt with marine OC on a 1:1 basis, we add the marine $\mathrm{OC}$ in addition to existing sources of OC and do not replace sea salt (S $\sigma$-ORG-ADD). This allows the number and mass concentrations to increase. The combined organic-inorganic source function is applied only to submicron size ranges, and all of the primary marine organic sea spray emitted is added to the hydrophobic OC size-resolved species in the GISS-TOMAS model.

It is currently unclear whether marine OC emissions displace sea salt, completely or partially, or occur in addition to sea salt. Physically, it depends on how organics affect the volume and composition of material ejected by windgenerated bubble bursting. We assume that $\mathrm{OC}$ replacement is more likely to happen, but test both methods as mentioned previously. Because the organics are likely sitting at the airsurface interface as either a microphase or a surface active monolayer and are not fully dissolved into bulk seawater, the volume mobilized by wind-generated bubble bursting will include a portion consisting of OC with little or no sea salt. In this scenario, the oceanic organic matter displaces some of what current sea salt parameterizations consider to be only sea salt and water, and thus the combined organic-inorganic source function should subtract sea salt and add OC. However, because seawater is dilute, OC probably does not completely replace sea salt on a 1:1 basis. Oppo et al. (1999) gives a theoretical analysis of what the organic monolayer enrichment might look like.

Lumping primary marine organic emissions into the hydrophobic OC model tracer assigns a $\kappa$-value of 0.09 for those emissions (Table 1), which implies an average organic molar mass of around $0.280 \mathrm{~kg} \mathrm{~mol}^{-1}$, assuming an organic density of $1400 \mathrm{~kg} \mathrm{~m}^{-3}$. While this is done to avoid the computational burden of adding another model species, some studies have suggested that primary marine organics consist of larger macromolecules, which have lower hygroscopicities. Moore et al. (2008) inferred an average organic molar mass of $4.3 \mathrm{~kg} \mathrm{~mol}^{-1}$ (corresponding to $\kappa=0.006$ ) from $\mathrm{CCN}$ activation experiments of an estuarine seawater extract enriched in dissolved organics, but noted that a small amount of low-molecular-weight species may be preferentially lost during the enrichment process, so this $\kappa$-value may represent the lower limit of marine dissolved organic matter. Svenningsson et al. (2006) used aquatic Suwannee River fulvic acid (SRFA) to simulate the contribution of a polyacidic marine organic aerosol component and report an average molar mass of $0.732 \mathrm{~kg} \mathrm{~mol}^{-1}$ and density of $1500 \mathrm{~kg} \mathrm{~m}^{-3}$, which translates into a $\kappa$-value of 0.04 . Despite this simplifying assumption, we note that the overall $\kappa$ of the internally-mixed marine aerosol is fairly insensitive to our choice of $\kappa$ for primary marine organic emissions because of the relatively high mass fraction and $\kappa$-value of sodium chloride. Recalling that $\kappa$ of a mixture is a volume-weighted average of $\kappa$ of its individual components (Petters and Kreidenweis, 2007), the effect of primary marine organic emissions is to replace $\sim 15 \%$ of the sea salt $(\kappa=0.98)$ in sea spray with $\kappa=0.006$. Since our approach uses $\kappa=0.09$ for primary marine organic emissions instead of $\kappa=0.006$, it captures $92 \%$ of the change in the $\kappa$ of the mixed particle.

\subsubsection{Chemical aging rates}

We consider three different rates of chemical conversion from hydrophobic to hydrophilic organic aerosol. Each of these rates corresponds to a unique pair of simulations, as is described in Sect. 2.4 and outlined in Table 2. The results shown in this paper are solely for a chemical conversion 
Table 2. Model simulations performed.

\begin{tabular}{llll}
\hline Description & "Fast" aging (1.5d) & "Slow" aging (4.5 d) & No Aging \\
\hline Marine organic emissions & F-ORG & S-ORG & N-ORG \\
No marine organics & F-BASE & S-BASE & N-BASE \\
Marine organic emissions with surfactant & F $\sigma$-ORG & S $\sigma$-ORG & N $\sigma$-ORG \\
No marine organics with surfactant & F $\sigma$-BASE & S $\sigma$-BASE & N $\sigma$-BASE \\
Marine organic emissions with addition of mass and number & - & S $\sigma$-ORG-ADD & - \\
\hline
\end{tabular}

timescale of 4.5 days. This is consistent with chemical aging rates observed for marine aerosol by Maria et al. (2004), which reported an oxidation rate of $17 \%$ organic carbon per day. Other rates explored and simulated, representing upper and lower bounds on aging rates and are described in Sect. 2.4. Results from the other aging cases are not shown here since they do not differ greatly from the base case aging timescale of 4.5 days.

\subsubsection{Surfactant effects}

Surfactants in the organic fraction may decrease activating cloud droplet surface tension thereby facilitating CCN activation (Facchini et al., 1999). These effects were considered in some of the simulations performed here. Data taken from seawater samples off the coast of Georgia, United States, show a nonlinear decreasing trend in surface tension with increasing water-soluble organic carbon concentration (Moore et al., 2008). The relation between surface tension and carbon concentration follows the Szyskowski-Langmuir fit (Langmuir, 1917):

$\sigma=\sigma_{\mathrm{w}}-\alpha T \ln (1+\beta C)$

where $\sigma_{\mathrm{w}}$ represents the surface tension of pure water, $T$ is temperature, $C$ is carbon concentration in the activating droplet (mass per volume), and $\alpha$ and $\beta$ are fitting parameters. The data used here from Moore et al. (2008) is representative of natural marine dissolved organic matter (DOM) and agrees with inferred surface tension depression calculated from Köhler theory. Other fits, such as one presented in Cavalli et al. (2004), yield stronger surface tension depression values but are not considered here.

Surface tension is a parameter in the Kelvin term of Köhler theory (exponential term in Eq. 3), which determines the supersaturation $(S)$ required for a particle to activate into a cloud nucleus as a function of particle wet diameter $\left(D_{\text {wet }}\right)$. Other variables in the Kelvin term (temperature $T$ in Kelvin, universal gas constant $R$, molecular weight of water $M_{\mathrm{w}}$, and density of water $\rho_{\mathrm{w}}$ ) remain unchanged. The reduced surface tension of the activating droplet weakens the Kelvin effect and results in lower critical supersaturations $\left(S_{\mathrm{c}}\right.$, the maximum of Eq. 3). The surfactants augment the $\mathrm{CCN}$ activity of the aerosol, leading to higher $\mathrm{CCN}$ concentrations at a given supersaturation. The competing Raoult effect is presented here in terms of the hygroscopicity parameter $(\kappa)$, particle wet diameter $\left(D_{\text {wet }}\right)$, and particle dry diameter $\left(D_{\text {dry }}\right)$.

$$
S=\frac{D_{\text {wet }}-D_{\text {dry }}}{D_{\text {wet }}^{3}-D_{\text {dry }}^{3}(1-\kappa)} \exp \left(\frac{4 M_{\mathrm{w}} \sigma}{R T \rho_{\mathrm{w}} D_{\text {wet }}}\right)
$$

In order to apply the effect of surfactants to the GISSTOMAS model, we modified the activation and wet deposition calculations to accept a variable surface tension instead of a fixed value (previously the surface tension of water). Surface tension in the model is now a function of composition and critical diameter, the latter of which is used to find the volume of water in the activating cloud droplets. In Eq. (2), carbon mass concentration is determined from the hydrophobic plus hydrophilic organic carbon per water volume in the droplet at the point of activation. Total (hydrophobic plus hydrophilic) organic aerosol mass was chosen in order to capture a maximum surface tension depression effect as well as for consistency with the measurements taken by Moore et al. (2008).

\subsection{Description of simulations}

Twelve simulations were carried out (Table 2) for twelve months each plus three months of spin-up. F-ORG and FBASE refer to two simulations using the same "fast" aging timescale (1.5 days) but differ in that F-ORG contains a primary marine organic source function whereas F-BASE does not. Similarly, N-ORG and N-BASE refer to two simulations in which there is no chemical aging and the entirety of the primary marine organic aerosol exists as hydrophobic organic carbon. Results in this study represent differencing between S-ORG and S-BASE, allowing for isolation of the marine organic aerosols under the "slow" aging lifetime of 4.5 days. $\mathrm{F} \sigma-, \mathrm{S} \sigma-$, and $\mathrm{N} \sigma-\mathrm{ORG}$ and BASE refer to the same simulations described above with the exception that organic aerosol is considered to be surface active, allowing for estimation of surfactant effects. Finally, sensitivity to assumptions of replacement or addition of marine organic aerosol with respect to existing sea salt is tested in the $\mathrm{S} \sigma$ ORG-ADD simulation. 
Table 3. Global aerosol budgets for marine organic aerosol simulations.

\begin{tabular}{|c|c|c|c|}
\hline Burden (Tg) & S-ORG & S-BASE & Difference \\
\hline Hydrophobic OC & 0.22 & 0.16 & 0.06 \\
\hline Hydrophilic OC & 0.71 & 0.64 & 0.07 \\
\hline Sea Salt & 13.39 & 13.52 & -0.13 \\
\hline Lifetime (d) & S-ORG & S-BASE & Difference \\
\hline Hydrophobic OC & 1.69 & 1.91 & - \\
\hline Hydrophilic OC & 5.31 & 5.33 & - \\
\hline Sea Salt & 0.67 & 0.68 & - \\
\hline Emissions $\left(\mathrm{Tg} \mathrm{yr}^{-1}\right)$ & S-ORG & S-BASE & Difference \\
\hline Hydrophobic OC & 48.2 & 30.5 & 17.7 \\
\hline Hydrophilic OC & 30.5 & 30.5 & 0 \\
\hline Sea Salt & 7294 & 7312 & -18 \\
\hline Aging $\left(\mathrm{Tg} \mathrm{yr}^{-1}\right)$ & S-ORG & S-BASE & Difference \\
\hline Hydrophobic OC & 18.3 & 13.2 & 5.1 \\
\hline Wet deposition $\left(\mathrm{Tg} \mathrm{yr}^{-1}\right)$ & S-ORG & S-BASE & Difference \\
\hline Hydrophobic OC & 28.7 & 16.6 & 12.1 \\
\hline Hydrophilic OC & 47.1 & 42.3 & 4.8 \\
\hline Sea Salt & 2621 & 2638 & -17 \\
\hline Dry deposition $\left(\mathrm{Tg} \mathrm{yr}^{-1}\right)$ & S-ORG & S-BASE & Difference \\
\hline Hydrophobic OC & 1.17 & 0.661 & 0.509 \\
\hline Hydrophilic OC & 1.65 & 1.44 & 0.21 \\
\hline Sea Salt & 4669 & 4670 & -1 \\
\hline
\end{tabular}

\section{Results}

\subsection{Global aerosol budgets}

Table 3 shows annually averaged global aerosol emission rates and burdens from the GISS-TOMAS model simulations. The third column labelled "Difference" shows values representative of only marine organic aerosol influence. As seen in the table, the total primary marine organic emission source is $17.7 \mathrm{TgC}^{-1}$. For comparison, this is approximately $13 \%$ of the global monoterpene emission flux reported by Guenther et al. (1995). As expected, sea-salt emissions decrease by the same amount that organic emissions increase. Globally averaged emission rates and burden of organic aerosol are higher by 30 and $16 \%$, respectively, for the organic-enrichment simulations (S-ORG) compared to the base case (S-BASE). The main sources of hydrophilic $\mathrm{OC}$ are chemical aging and emission, whereas chemical aging serves as a sink for hydrophobic OC. Wet and dry deposition are the major sinks for sea salt and both types of OC. The sea salt budget is dominated by the coarse mode and therefore is largely unchanged since marine organic OC emissions were limited to submicron sizes.
The main difference between the slow aging case presented here (S-ORG/BASE) and the other two cases (FORG/BASE and N-ORG/BASE) is the magnitude of the aging term. The aging budget information for the $\mathrm{N}$ ORG/BASE case is $0 \mathrm{Tg} \mathrm{yr}^{-1}$ for both simulations since those simulations have no aging occurring. For the FORG/BASE simulations, aging is happening quite a bit faster than in the S-ORG/BASE scenarios. In F-ORG and F-BASE cases, aging is responsible for $28 \mathrm{Tg} \mathrm{yr}^{-1}$ and $20 \mathrm{Tg} \mathrm{yr}^{-1}$, respectively. As shown in Table 3, S-ORG and S-BASE having aging budget values of 18 and $13 \mathrm{Tg} \mathrm{yr}^{-1}$, respectively.

\subsection{Surface mass concentration}

Figure 1 shows the sea salt mass concentrations and total organic aerosol mass concentrations for the Northern Hemisphere summer (JJA) and winter (DJF) months. Maximum concentrations of sea salt (panels A and B) are shown for the S-BASE simulation and are predicted to occur in the mid-to-upper latitudes in both the Northern and Southern Hemispheres. For marine organic aerosol (panels C and D) Fig. 1 represents the difference between concentrations with (S-ORG) and without (S-BASE) the primary marine organic source function. Panels $E$ and $F$ show the base case concentrations for each set of months (S-BASE). In the winter months during periods of high biological activity in the Southern Ocean, concentrations of organic aerosol reach a maximum of $2 \mu \mathrm{g} \mathrm{m}^{-3}$. For the summer months, similar maximum concentrations of primary marine organic aerosol are reached in the northern Atlantic and Pacific Oceans. Because of the higher winds and less variability in the chlorophyll- $a$ concentrations in the Southern Hemisphere compared to the Northern Hemisphere, the oceanic organic aerosol source remains significant during the Southern Hemisphere winter months (JJA). The globally averaged surface concentrations for primary marine organic aerosol are 0.16 and $0.12 \mu \mathrm{g} \mathrm{m}^{-3}$ for DJF and JJA, respectively.

Different aging scenarios and the split between hydrophobic and hydrophilic OC are not shown because their conclusions regarding $\mathrm{CCN}$ and mass concentrations are quite similar to the S-ORG and S-BASE simulations. In F-ORG and F-BASE, a much higher fraction of the organic aerosol exists in the hydrophilic OC form, whereas in the N-ORG and N-BASE simulations, no organic aerosol exists in the hydrophilic form. In every case, surface concentrations of organic aerosol are enhanced in ocean locations by up to $2 \mu \mathrm{g} \mathrm{m}^{-3}$.

\subsection{Model evaluation against observations}

Recently, two observational data sets of marine aerosols from remote sites with high biological activity have become available. These datasets were taken at Mace Head $\left(53^{\circ} 19.5^{\prime} \mathrm{N}\right.$, $9^{\circ} 54^{\prime} \mathrm{W}$ ) and Amsterdam Island $\left(37^{\circ} 49^{\prime} \mathrm{S}, 77^{\circ} 33^{\prime} \mathrm{E}\right.$ ) (Sciare et al., 2009; Yoon et al., 2007). Model predictions are 



Fig. 1. Total sea salt (panels $\mathbf{A}$ and $\mathbf{B}$ ) and marine organic aerosol (panels $\mathbf{C}$ and $\mathbf{D}$ ) mass concentrations (in $\mu \mathrm{g} \mathrm{m}^{-3}$ ) at the surface for a three-month seasonal average over December, January, and February (panels A and C), and June, July, and August (panels B and D). For the same set of months, panels (E) and (F) show the surface mass concentrations of organic aerosol without the marine organic source function. Concentrations are calculated at a standard a temperature of $273 \mathrm{~K}$ and pressure of $1000 \mathrm{hPa}$.

presented against the Mace Head and Amsterdam Island data sets, being representative locations for both the Northern and Southern Hemispheres (Fig. 2). The data used for the Mace Head comparison is not filtered by black carbon concentration or wind direction as described in Cavalli et al. (2004). At Mace Head, the model predicts observed concentrations within a factor of two for many of the months. The log mean normalized bias (LMNB) averaged over the full year is 0.36 , compared to -1.26 in the base case without marine organics. The correlation coefficient also improves from -0.115 without marine organics to 0.248 with them. When using the ORG-ADD simulation results, the model biases are larger, as seen in the grey and light red trace in Fig. 2. At Amsterdam Island, the model consistently predicts higher concentrations than the observations. Here, the LMNB is 0.51 with marine organics, compared to -0.79 without them, indicating that the simulations with marine organics over-predict by a factor of 3 on average. For this location, despite the improvement in LMNB, the model does not capture the trend seen in the observations and there is no improvement in the correlation coefficient. Although significant model-measurement disagreement is evident, it is clear that the updated model is an improvement over the same model without the implementation of the O'Dowd et al. (2008) source function. The LMNB values after including marine organic emissions suggest that the model overpredicts OC mass concentrations by a factor of 2 and 3 at Mace Head and Amsterdam Island, respectively, biases that are typical of global aerosol models in general and of sea spray in particular. For example, AEROCOM found biases ranging from a factor of 2 to 10 , depending on the model used in the comparison (Textor et al., 2006). However, it should be pointed out that our model has a tendency to overpredict $\mathrm{OC}$ with the inclusion of marine sources while it tends to underpredict sea salt mass concentrations (Pierce 

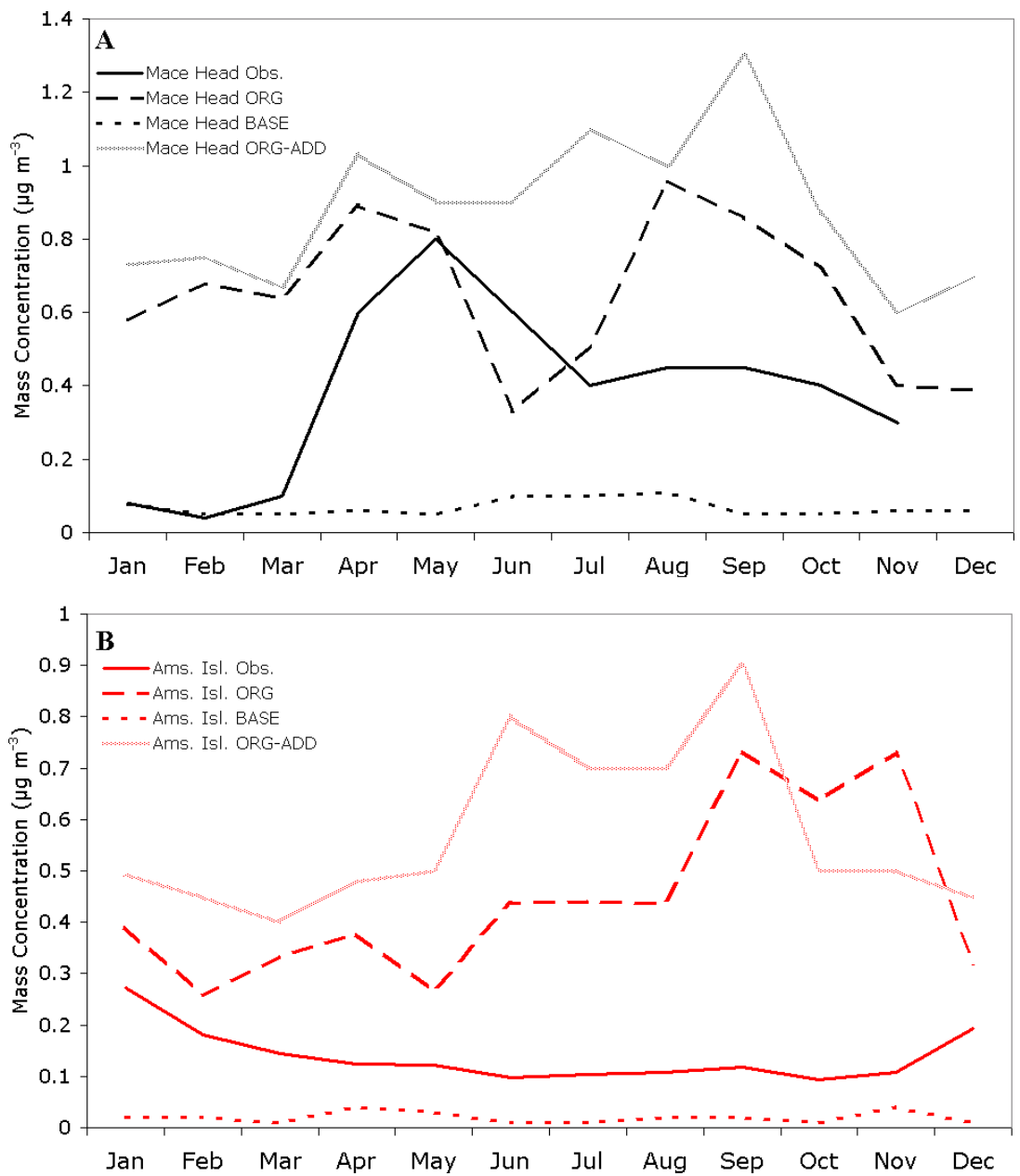

Fig. 2. Model and measurement comparison of total organic aerosol concentrations at two locations. Solid lines represent observations at Mace Head (black, panel A) and Amsterdam Island (red, panel B), and long dashed lines represent modelled values with marine organic enhancement at Mace Head (black) and Amsterdam Island (red). Short dashed lines represent model predictions at Mace Head (black) and Amsterdam Island (red) for simulations without the marine organic source function. The grey line in panel (A) and lighter shade of red in panel (B) represent model values at Mace Head and Amsterdam Island when the replacement assumption is not used ("ORG-ADD" simulation). Model values are reported for total organic aerosol, both hydrophobic and hydrophilic. Measured data is in the form of WIOC + WSOC.

and Adams, 2006). These limited results suggest, therefore, that the ratio of $\mathrm{OC}$ to sea salt in the emissions parameterization used here may be biased high.

The model comparison to the Amsterdam Island measurements is the best during the austral summer months (DJF), where the differences are around $50 \%$. Similarly, the model shows best agreement with measurements at Mace Head in the Northern Hemisphere spring and summer. When biological activity is at a maximum, modelled and measured marine organic aerosol are in good agreement. At both Mace Head and Amsterdam Island, model predictions are as much as a factor of 5 or 10 higher than observed values during the winter time in each hemisphere, when biological activity is lowest. Errors in the model predictions are likely the result of the simplicity of the marine organic aerosol source function. A correlation between organic fraction and chlorophyll- $a$ is not observed at Amsterdam Island as it is at Mace Head (Claeys et al., 2010), thus it is not surprising that model error is larger. Nevertheless, in the absence of primary marine organic emissions, the model greatly underestimates organic aerosol concentrations at these sites.

\subsection{Impacts of primary $\mathrm{OC}$ emissions on $\mathrm{CCN}$ concentrations}

Figure $3 \mathrm{a}$ and $\mathrm{b}$ show the percent change in $\mathrm{CCN}(0.2 \%)$ concentrations without surface tension depression effects of the organic aerosol for Northern Hemisphere winter (DJF) and summer (JJA) months. $\mathrm{CCN}(0.2 \%)$ concentrations decrease, reflecting the decrease in aerosol solubility. The 

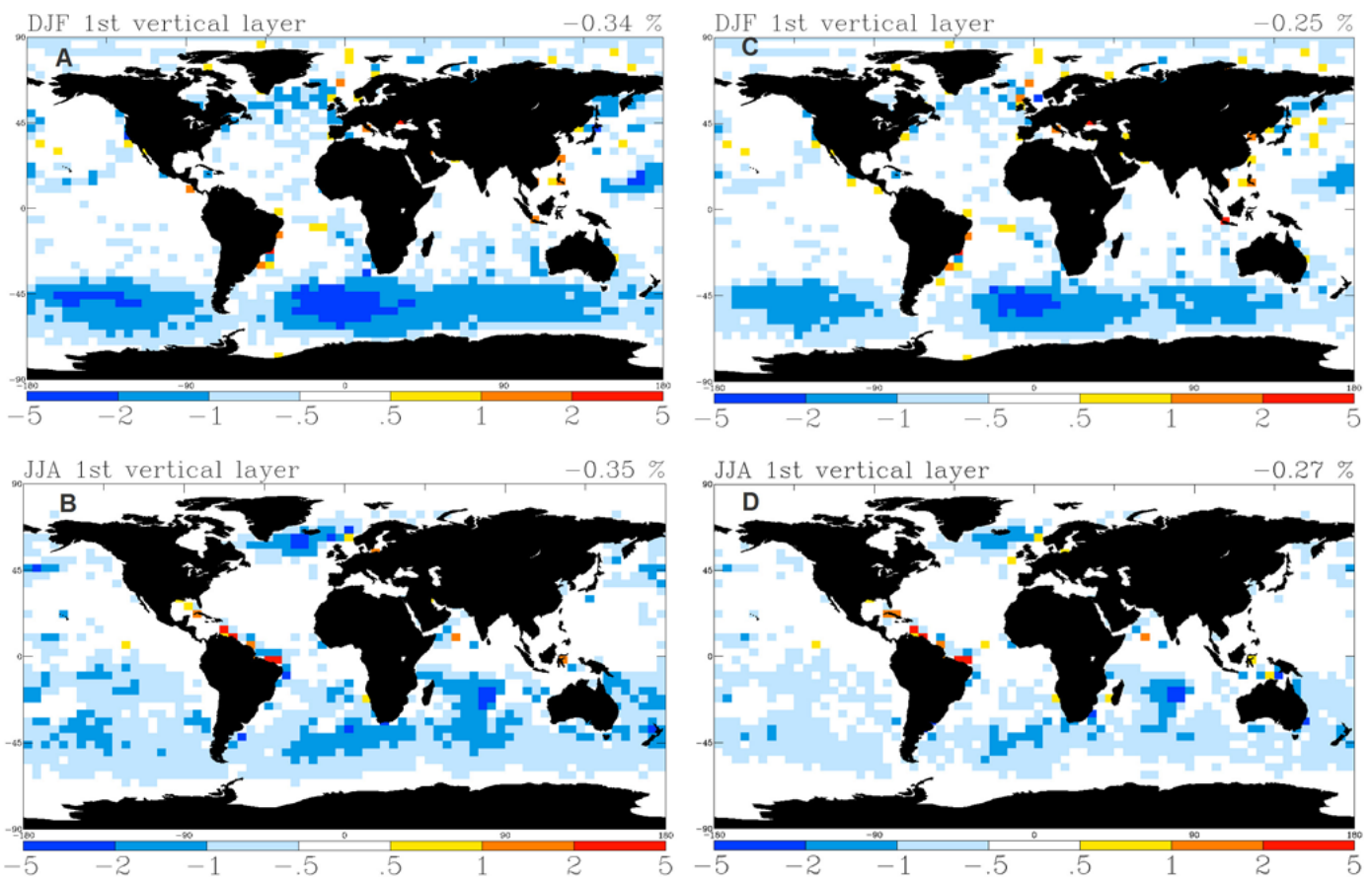

Fig. 3. Relative change (in percent) in $\mathrm{CCN}(0.2 \%)$ concentrations ignoring surfactant effects (panels $\mathbf{A}$ and $\mathbf{B})$ and with surfactant effects (panels $\mathbf{C}$ and $\mathbf{D}$ ) of marine organic aerosols for a three-month seasonal average over December, January, and February (panels $\mathbf{A}$ and $\mathbf{C}$ ), and June, July, and August (panels $\mathbf{B}$ and $\mathbf{D})$.

global change is less than $1 \%$ but up to $5 \%$ in the areas of high ocean biological activity. In the austral summer (DJF), $\mathrm{CCN}(0.2 \%)$ concentrations decrease by as much as $5 \%$ in the Southern Ocean. The locations of the strongest CCN decreases appear in regions containing high primary marine organic aerosol (Fig. 1).

Figure $3 \mathrm{c}$ and $\mathrm{d}$ show the percent change of $\mathrm{CCN}(0.2 \%)$ concentrations with inclusion of surface tension depression effects of the organic aerosol for DJF and JJA months. These results follow similar trends as when surface tension effects were ignored, except that the magnitude of the changes is slightly smaller. The surface tension depression of the organic compounds in the internally mixed aerosol enhances $\mathrm{CCN}$ concentrations compared to the case without surfactant effects. However, the increase in $\mathrm{CCN}$ due to surfactant effects is outweighed by the decrease in $\mathrm{CCN}$ due to lower aerosol solubility.

Figure 4 shows the percent change of $\mathrm{CCN}(0.2 \%)$ concentrations assuming that marine organics do not replace sea salt aerosol ( $\sigma \sigma$-ORG-ADD simulation). In this plot, surfactant effects are included. We find that the sign and the magnitude of the CCN effect changes significantly when compared with the replacement assumption (S-ORG simulation). The increases in $\mathrm{CCN}(0.2 \%)$ concentrations can be explained by the manner that the source function was applied in these simulations. For these simulations, number and mass of marine organic aerosol is an additional source that does not displace any sea salt. More aerosol number, despite the low hygro- scopicity, will lead to more CCN. Similar to the replacement of sea salt simulations, the strongest changes are predicted in the Southern Ocean in both DJF (panel A) and JJA (panel B). The $\mathrm{CCN}(0.2 \%)$ concentrations now increase when compared to a base case simulation by as much as $25-50 \%$ in the Southern Ocean during the austral summer. In contrast, Northern Hemisphere summer increases in $\mathrm{CCN}(0.2 \%)$ are in the $10-25 \%$ range. Globally averaged the increases are $3.7 \%$ for the DJF months and $2.9 \%$ for JJA.

To explain why the fixed aerosol number and mass cases result in such a minor CCN sensitivity (Fig. 3), Fig. 5 shows the activation curves (DJF) for aerosol in the middle of the Southern Ocean $\left(45^{\circ} 0^{\prime} \mathrm{S}, 0^{\circ} 0^{\prime} \mathrm{E}\right)$ and for pure species sea salt $(\kappa=0.98)$ and hydrophilic organic aerosol $(\kappa=0.2)$. This particular location is an area of high biological production with relatively small continental pollution influence and, therefore, exhibits one of the largest percent decreases in $\mathrm{CCN}(0.2 \%)$ due to marine organic emissions. At this location, an aerosol of dry diamater $92 \mathrm{~nm}$ has a critical supersaturation of $0.2 \%$ and is roughly $15 \%$ hydrophobic organic, $5 \%$ hydrophilic organic, $60 \%$ seasalt, and $20 \%$ sulfate. As expected, the activation curves for this location follow more closely the behavior of sea salt than organic aerosol, which remains the dominant component even in this area of high biological productivity. The activation curves for both of the organically enriched size distributions are shifted to the right of the base case, in which the composition is $5 \%$ hydrophilic organic, $75 \%$ seasalt, and $20 \%$ sulfate. The critical 

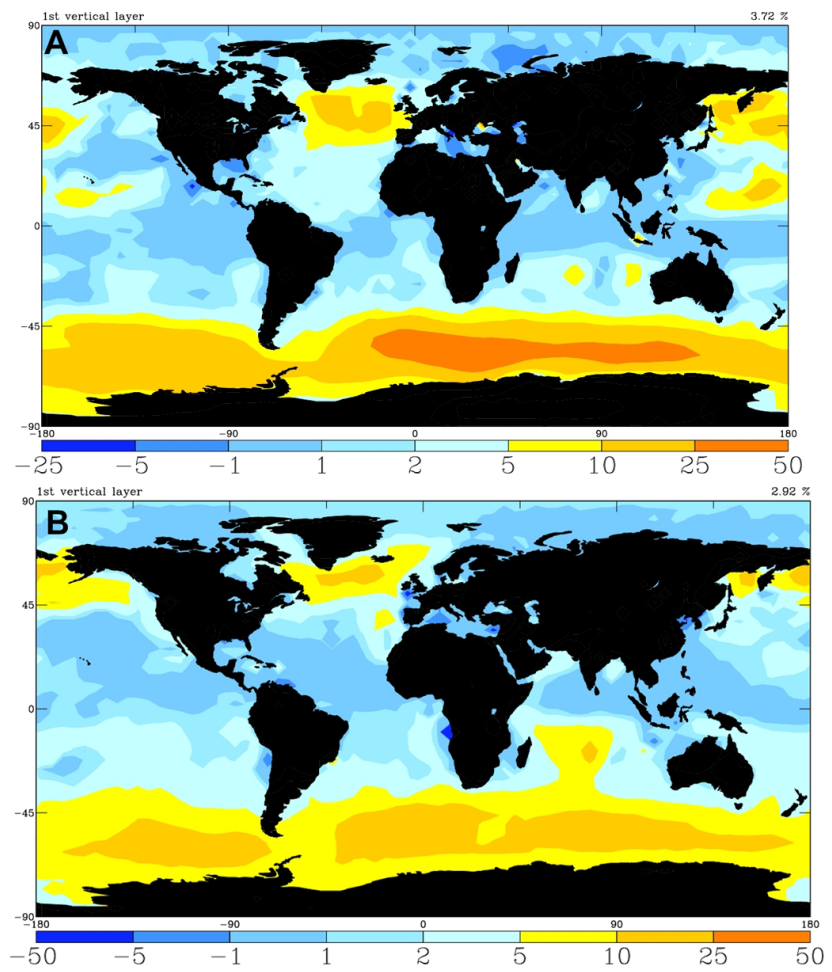

Fig. 4. Relative change (in percent) in $\mathrm{CCN}(0.2 \%)$ concentrations assuming that marine OC does not replace sea salt and is instead added on top of existing sea spray aerosol (S $\sigma$-ORG-ADD versus $\mathrm{S} \sigma$-BASE-ADD). Panel (A) is a three-month seasonal average over December, January, and February, and panel $(\mathbf{B})$ is averaged over June, July, and August. In both simulations, marine organics are treated as surfactants.

diameter at $0.2 \%$ supersaturation shifts only a small amount (from about 84 to $92 \mathrm{~nm}$ ) with the marine organic enhancement. When surface tension depression effects are included, the suppression of the Kelvin effect by the lowered surface tension shifts the critical diameter back to around $89 \mathrm{~nm}$, partially offsetting the solubility effect of marine organic aerosol on $\mathrm{CCN}(0.2 \%)$ concentrations. This critical diameter decrease from surfactant effects yields less than a $2 \%$ change on overall CCN concentrations, consistent with predicted aerosol number size distributions for the region.

The number size distribution function for this region in the fixed aerosol number and mass assumption scenario (SORG) confirms the small (1 to $5 \%$ ) changes in overall CCN. The shape of the distribution functions for the S-BASE and S-ORG cases are virtually the same (not shown), which highlights that primary marine organic aerosol does not drastically change the overall microphysics. Instead, the $\mathrm{CCN}$ changes result almost entirely from the shift in aerosol activation diameter.

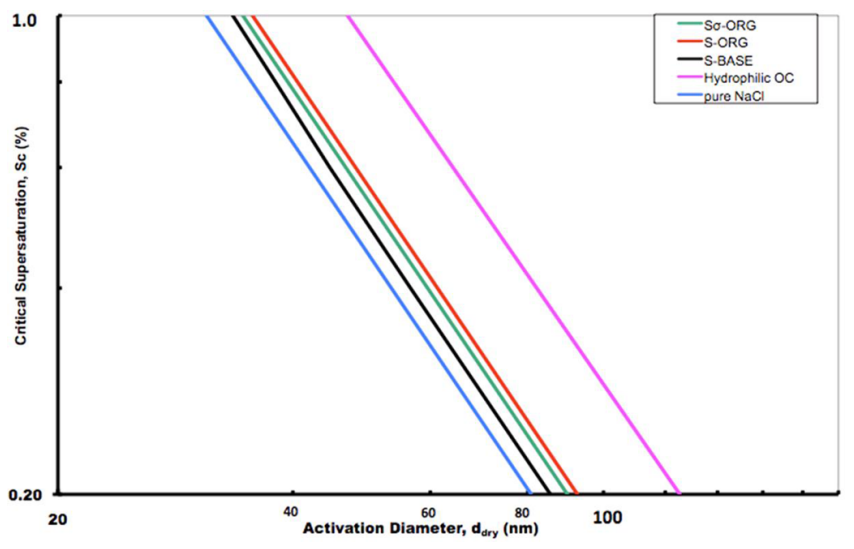

Fig. 5. $S_{\mathrm{c}}$ (critical supersaturation) versus $D_{\text {dry }}$ (dry aerosol diameter) plot for modeled marine aerosols in Southern Ocean $\left(45^{\circ} 0^{\prime} \mathrm{S}\right.$, $\left.0^{\circ} 0^{\prime} \mathrm{E}\right)$. The black line represents model results for base case marine aerosols (no marine organic emissions). The green and red lines represent model output for organically enhanced marine aerosols with and without surface tension depression effects included. The magenta and blue lines represent pure species of hydrophilic OC and sea salt, respectively, and provide a frame of reference for our model simulations.

\section{Conclusions}

Model simulations were performed with a modified version of the GISS-TOMAS global aerosol model to determine the sensitivity of cloud condensation nuclei to marine organic sea-spray aerosol emissions. The global emission source of primary marine organics was estimated to be $17.7 \mathrm{Tg} \mathrm{yr}^{-1}$ or $20 \%$ of the total modelled OC emission source. Modelled and measured monthly averaged surface concentrations of marine organic aerosol agree to within a factor of two or better for several months of the year, particularly during periods of biological activity. However, discrepancies in the model-measurement comparison can be as large as a factor of 5. When compared to a base case model without marine organics, the O'Dowd et al. (2008) source function improves the model prediction of OC mass concentrations at both locations examined here, Mace Head and Amsterdam Island. Our errors are in the same range that global aerosols models have previously reported for sea salt. Thus, we cannot unambiguously attribute the errors to the marine organic source function alone since predictions of marine OC concentrations will be affected by the same errors as sea salt, including errors in model wind speed. Nevertheless, we expect that improvements in the marine organic source function are possible.

Surfactant effects were simulated in order to obtain the complete effect of the marine emission source. When surfactant effects are not considered, we find that $\mathrm{CCN}(0.2 \%)$ concentrations decrease by about $5 \%$ in biologically active regions assuming total sea spray aerosol number and mass (sea salt and organic) remained fixed. Impacts on $\mathrm{CCN}(0.2 \%)$ concentrations are less than $0.5 \%$ over most of the ocean 
surface. The CCN decreases are due to the replacement of a soluble sea-salt composition with a less soluble hydrophobic organic aerosol. The effect is relatively small due to the small $(\sim 15 \%)$ compositional changes induced by the primary organic emissions. When surfactant effects are considered, the effect of decreased solute is partially offset by the ability of surfactants to lower surface tension and enable CCN activation. Changes in $\operatorname{CCN}(0.2 \%)$ with surface tension depression effects considered are about -1 to $-5 \%$ regionally and $-0.25 \%$ globally. When we hold $\mathrm{NaCl}$ mass emissions fixed and add marine OC mass, increasing sea spray number flux accordingly, we find that $\mathrm{CCN}$ increase by up to $50 \%$ regionally and $3.7 \%$ globally. With these assumptions, marine organic aerosol does appear to be a major player in regional $\mathrm{CCN}$ with modest but non-negligible global influence. However, these sensitivity simulations are high speculative, and modelled ambient concentrations at Mace Head are in better agreement to measurements when the replacement assumption is used ("ORG" simulations).

Since our emission source is almost a factor of two larger than several past studies (Gantt et al., 2009; Spracklen et al., 2008; Vignati et al., 2009), our predicted CCN impacts may be correspondingly high. Only the Roelofs (2008) study had a higher emission source than the work presented here. The $5 \% \mathrm{CCN}$ sensitivity is not likely significant since it falls below the average CCN prediction error of $9 \%$ when using Kohler theory with size-resolved aerosol composition measurements (Sotiropoulou et al., 2006). Therefore, this result suggests that it is unlikely that primary marine organic aerosol significantly affects $\mathrm{CCN}$ concentrations, both globally and regionally. However, when aerosol number is not held fixed, significant $\mathrm{CCN}$ concentrations result from marine organic sources. These two scenarios provide bounding cases on the possible effects of marine organic aerosol on $\mathrm{CCN}$. Different assumptions, such as the fixing of aerosol number, lead to vastly different results. Future work is needed to fully determine the physical mechanism behind sea spray aerosol emissions, and future measurements should move beyond marine OC mass to investigate carefully how and whether sea salt mass and aerosol number emissions fluxes change between biologically inactive and active regions.

Acknowledgements. The authors would like to thank Jeffrey Pierce for his knowledge on global sea spray emissions. R. H. M. acknowledges support from a NASA ESS fellowship.

Edited by: K. Carslaw

\section{References}

Adams, P. J. and Seinfeld, J. H.: Predicting global aerosol size distributions in general circulation models, J. Geophys. Res., 107, 4370, doi:10.1029/2001jd001010, 2002.

Adams, P. J. and Seinfeld, J. H.: Disproportionate impact of particulate emissions on global cloud condensation nuclei concentrations, Geophys. Res. Lett., 30, 1239, doi:10.1029/2002gl016303, 2003.

Arnold, S. R., Spracklen, D. V., Williams, J., Yassaa, N., Sciare, J., Bonsang, B., Gros, V., Peeken, I., Lewis, A. C., Alvain, S., and Moulin, C.: Evaluation of the global oceanic isoprene source and its impacts on marine organic carbon aerosol, Atmos. Chem. Phys., 9, 1253-1262, doi:10.5194/acp-9-1253-2009, 2009.

Bond, T. C., Streets, D. G., Yarber, K. F., Nelson, S. M., Woo, J. H., and Klimont, Z.: A technology-based global inventory of black and organic carbon emissions from combustion, J. Geophys. Res.-Atmos., 109, D14203, doi:10.1029/2003jd003697, 2004.

Cavalli, F., Facchini, M. C., Decesari, S., Mircea, M., Emblico, L., Fuzzi, S., Ceburnis, D., Yoon, Y. J., O’Dowd, C. D., Putaud, J. P., and Dell'Acqua, A.: Advances in characterization of size-resolved organic matter in marine aerosol over the North Atlantic, J. Geophys. Res., 109, D24215, doi:10.1029/2004jd005137, 2004.

Clarke, A. D., Owens, S. R., and Zhou, J. C.: An ultrafine seasalt flux from breaking waves: Implications for cloud condensation nuclei in the remote marine atmosphere, J. Geophys. Res.Atmos., 111, D06202, doi:10.1029/2005jd006565, 2006.

Dana, M. T. and Hales, J. M.: Statistical Aspects of Washout of Polydisperse Aerosols, Atmos. Environ., 10, 45-50, 1976.

Del Genio, A. D., Yao, M.-S., Kovari, W., and Lo, K. K.W.: A Prognostic Cloud Water Parameterization for Global Climate Models, J. Climate, 9, 270-304, doi:10.1175/15200442(1996)009<0270:APCWPF>2.0.CO;2, 1996.

El-Zanan, H. S., Lowenthal, D. H., Zielinska, B., Chow, J. C., and Kumar, N.: Determination of the organic aerosol mass to organic carbon ratio in IMPROVE samples, Chemosphere, 60, 485-496, 2005.

Facchini, M. C., Mircea, M., Fuzzi, S., and Charlson, R. J.: Cloud albedo enhancement by surface-active organic solutes in growing droplets, Nature, 401, 257-259, 1999.

Facchini, M. C., Rinaldi, M., Decesari, S., Carbone, C., Finessi, E., Mircea, M., Fuzzi, S., Ceburnis, D., Flanagan, R., Nilsson, E. D., de Leeuw, G., Martino, M., Woeltjen, J., and O'Dowd, C. D.: Primary submicron marine aerosol dominated by insoluble organic colloids and aggregates, Geophys. Res. Lett., 35, L17814, doi:10.1029/2008g1034210, 2008.

Fuentes, E., Coe, H., Green, D., de Leeuw, G., and McFiggans, G.: On the impacts of phytoplankton-derived organic matter on the properties of the primary marine aerosol - Part 1: Source fluxes, Atmos. Chem. Phys., 10, 9295-9317, doi:10.5194/acp-10-92952010, 2010.

Gantt, B., Meskhidze, N., and Kamykowski, D.: A new physically-based quantification of marine isoprene and primary organic aerosol emissions, Atmos. Chem. Phys., 9, 4915-4927, doi:10.5194/acp-9-4915-2009, 2009.

Gantt, B., Meskhidze, N., Facchini, M. C., Rinaldi, M., Ceburnis, D., and O'Dowd, C. D.: Wind speed dependent size-resolved parameterization for the organic mass fraction of sea spray aerosol, 
Atmos. Chem. Phys., 11, 8777-8790, doi:10.5194/acp-11-87772011, 2011.

Gogou, A. I., Apostolaki, M., and Stephanou, E. G.: Determination of organic molecular markers in marine aerosols and sediments: one-step flash chromatography compound class fractionation and capillary gas chromatographic analysis, J. Chromatogr. A, 799, 215-231, 1998.

Gong, S. L.: A parameterization of sea-salt aerosol source function for sub- and super-micron particles, Global Biogeochem. Cy., 17, 1097, doi:10.1029/2003gb002079, 2003.

Guenther, A., Hewitt, C. N., Erickson, D., Fall, R., Geron, C., Graedel, T., Harley, P., Klinger, L., Lerdau, M., McKay, W. A., Pierce, T., Scholes, B., Steinbrecher, R., Tallamraju, R., Taylor, J., and Zimmerman, P.: A global model of natural volatile organic compound emissions, J. Geophys. Res., 100, 8873-8892, doi:10.1029/94jd02950, 1995.

Hansen, J., Russell, G., Rind, D., Stone, P., Lacis, A., Lebedeff, S., Ruedy, R., and Travis, L.: Efficient 3-Dimensional Global-Models for Climate Studies - Model-I and Model-Ii, Mon. Weather Rev., 111, 609-662, 1983.

Koch, D., Jacob, D., Tegen, I., Rind, D., and Chin, M.: Tropospheric sulfur simulation and sulfate direct radiative forcing in the Goddard Institute for Space Studies general circulation model, J. Geophys. Res.-Atmos., 104, 23799-23822, 1999.

Langmuir, I.: The construction and fundamental properties of solids and liquies. II. Liquids, American Chemical Society, 39, 18481906, 1917.

Lapina, K., Heald, C. L., Spracklen, D. V., Arnold, S. R., Allan, J. D., Coe, H., McFiggans, G., Zorn, S. R., Drewnick, F., Bates, T. S., Hawkins, L. N., Russell, L. M., Smirnov, A., O’Dowd, C. D., and Hind, A. J.: Investigating organic aerosol loading in the remote marine environment, Atmos. Chem. Phys., 11, 88478860, doi:10.5194/acp-11-8847-2011, 2011.

Lee, Y. H. and Adams, P. J.: Evaluation of aerosol distributions in the GISS-TOMAS global aerosol microphysics model with remote sensing observations, Atmos. Chem. Phys., 10, 2129-2144, doi:10.5194/acp-10-2129-2010, 2010.

Lee, Y. H. and Adams, P. J.: An efficient global cloud condensation nuclei model based on the TwO-Moment Aerosol Sectional (TOMAS) aerosol microphysics algorithm, in preparation, 2011.

Maria, S. F., Russell, L. M., Gilles, M. K., and Myneni, S. C. B.: Organic aerosol growth mechanisms and their climate-forcing implications, Science, 306, 1921-1924, doi:10.1126/Science.1103491, 2004.

Martensson, E. M., Nilsson, E. D., de Leeuw, G., Cohen, L. H., and Hansson, H. C.: Laboratory simulations and parameterization of the primary marine aerosol production, J. Geophys. Res., 108, 4297, doi:10.1029/2002jd002263, 2003.

Meskhidze, N. and Nenes, A.: Phytoplankton and cloudiness in the Southern Ocean, Science, 314, 1419-1423, doi:10.1126/Science.1131779, 2006.

Meskhidze, N., Xu, J., Gantt, B., Zhang, Y., Nenes, A., Ghan, S. J., Liu, X., Easter, R., and Zaveri, R.: Global distribution and climate forcing of marine organic aerosol: 1. Model improvements and evaluation, Atmos. Chem. Phys., 11, 11689-11705, doi:10.5194/acp-11-11689-2011, 2011.

Monahan, E. C.: Sea Spray as a Function of Low Elevation Wind Speed, J. Geophys. Res., 73, 1127-1137, 1968.

Monahan, E. C.: A model of marine aerosol generation via white- caps and wave disruption, in: Oceanic whitecaps, 167-193, 1986.

Moore, R. H., Ingall, E. D., Sorooshian, A., and Nenes, A.: Molar mass, surface tension, and droplet growth kinetics of marine organics from measurements of CCN activity, Geophys. Res. Lett., 35, L07801, doi:10.1029/2008g1033350, 2008.

Myriokefalitakis, S., Vignati, E., Tsigaridis, K., Papadimas, C., Sciare, J., Mihalopoulos, N., Facchini, M., Rinaldi, M., Dentener, F., Ceburnis, D., Hatzianastasiou, N., O'Dowd, C., van Weele, M., and Kanakidou, M.: Global Modeling of the Oceanic Source of Organic Aerosols, Advances in Meteorology, 2010, 939171, doi:10.1155/2010/939171, 2010.

O’Dowd, C. D., Facchini, M. C., Cavalli, F., Ceburnis, D., Mircea, M., Decesari, S., Fuzzi, S., Yoon, Y. J., and Putaud, J. P.: Biogenically driven organic contribution to marine aerosol, Nature, 431, 676-680, doi:10.1038/Nature02959, 2004.

O’Dowd, C. D., Langmann, B., Varghese, S., Scannell, C., Ceburnis, D., and Facchini, M. C.: A combined organic-inorganic sea-spray source function, Geophys. Res. Lett., 35, L01801, doi:10.1029/2007gl030331, 2008.

Oppo, C., Bellandi, S., Degli Innocenti, N., Stortini, A. M., Loglio, G., Schiavuta, E., and Cini, R.: Surfactant components of marine organic matter as agents for biogeochemical fractionation and pollutant transport via marine aerosols, Mar. Chem., 63, 235253, doi:10.1016/S0304-4203(98)00065-6, 1999.

Petters, M. D. and Kreidenweis, S. M.: A single parameter representation of hygroscopic growth and cloud condensation nucleus activity, Atmos. Chem. Phys., 7, 1961-1971, doi:10.5194/acp-71961-2007, 2007.

Pierce, J. R. and Adams, P. J.: Global evaluation of CCN formation by direct emission of sea salt and growth of ultrafine sea salt, J. Geophys. Res.-Atmos., 111 D06203, doi:10.1029/2005jd006186, 2006.

Pierce, J. R., Chen, K., and Adams, P. J.: Contribution of primary carbonaceous aerosol to cloud condensation nuclei: processes and uncertainties evaluated with a global aerosol microphysics model, Atmos. Chem. Phys., 7, 5447-5466, doi:10.5194/acp-75447-2007, 2007.

Prather, M. J.: Numerical Advection by Conservation of 2nd-Order Moments, J. Geophys. Res.-Atmos., 91, 6671-6681, 1986.

Raymond, T. M., and Pandis, S. N.: Formation of cloud droplets by multicomponent organic particles, J. Geophys. Res.-Atmos., 108, 4469, doi:10.1029/2003jd003503, 2003.

Roelofs, G. J.: A GCM study of organic matter in marine aerosol and its potential contribution to cloud drop activation, Atmos. Chem. Phys., 8, 709-719, doi:10.5194/acp-8-709-2008, 2008.

Russell, L. M., Hawkins, L. N., Frossard, A. A., Quinn, P. K., and Bates, T. S.: Carbohydrate-like composition of submicron atmospheric particles and their production from ocean bubble bursting, P. Natl. Acad. Sci. USA, 107, 6652-6657, doi:10.1073/Pnas.0908905107, 2010.

Sciare, J., Favez, O., Sarda-Esteve, R., Oikonomou, K., Cachier, H., and Kazan, V.: Long-term observations of carbonaceous aerosols in the Austral Ocean atmosphere: Evidence of a biogenic marine organic source, J. Geophys. Res.-Atmos., 114, D15302, doi:10.1029/2009jd011998, 2009.

Sotiropoulou, R. E. P., Nenes, A., Adams, P. J., and Seinfeld, J. H.: Cloud condensation nuclei prediction error from application of Kohler theory: Importance for the aerosol 
indirect effect, J. Geophys. Res.-Atmos., 112, 12, D1220210, doi:1029/2006jd007834, 2007.

Sorjamaa, R. and Laaksonen, A.: The influence of surfactant properties on critical supersaturations of cloud condensation nuclei, J. Aerosol Sci., 37, 1730-1736, 2006.

Spracklen, D. V., Arnold, S. R., Sciare, J., Carslaw, K. S., and Pio, C.: Globally significant oceanic source of organic carbon aerosol, Geophys. Res. Lett., 35, L12811, doi:10.1029/2008g1033359, 2008.

Svenningsson, B., Rissler, J., Swietlicki, E., Mircea, M., Bilde, M., Facchini, M. C., Decesari, S., Fuzzi, S., Zhou, J., Mønster, J., and Rosenørn, T.: Hygroscopic growth and critical supersaturations for mixed aerosol particles of inorganic and organic compounds of atmospheric relevance, Atmos. Chem. Phys., 6, 1937-1952, doi:10.5194/acp-6-1937-2006, 2006.

Tervahattu, H., Hartonen, K., Kerminen, V.-M., Kupiainen, K., Aarnio, P. I., Koskentalo, T., Tuck, A. F., and Vaida, V.: New evidence of an organic layer on marine aerosols, J. Geophys. Res., 107, 4053, doi:10.1029/2000jd000282, 2002a.

Tervahattu, H., Juhanoja, J., and Kupiainen, K.: Identification of an organic coating on marine aerosol particles by TOF-SIMS, J. Geophys. Res.-Atmos., 107, 4319, doi:10.1029/2001jd001403, 2002b.

Textor, C., Schulz, M., Guibert, S., Kinne, S., Balkanski, Y., Bauer, S., Berntsen, T., Berglen, T., Boucher, O., Chin, M., Dentener, F., Diehl, T., Easter, R., Feichter, H., Fillmore, D., Ghan, S., Ginoux, P., Gong, S., Grini, A., Hendricks, J., Horowitz, L., Huang, P., Isaksen, I., Iversen, I., Kloster, S., Koch, D., Kirkevåg, A., Kristjansson, J. E., Krol, M., Lauer, A., Lamarque, J. F., Liu, X., Montanaro, V., Myhre, G., Penner, J., Pitari, G., Reddy, S., Seland, Ø., Stier, P., Takemura, T., and Tie, X.: Analysis and quantification of the diversities of aerosol life cycles within AeroCom, Atmos. Chem. Phys., 6, 1777-1813, doi:10.5194/acp-61777-2006, 2006.
Twomey, S. A.: Pollution and Cloud Albedo, EOS T. Am. Geophys. Un., 58, 797-797, 1977.

Vignati, E., Facchini, M. C., Rinaldi, M., Scannell, C., Sciare, J., Kanakidou, M., Myriokefalitakis, S., Dentener, F., and O'Dowd, C.: Impact of global emissions of primary marine organic aerosols, Geochim. Cosmochim. Ac., 73, A1383-A1383, 2009.

Yao, M.-S. and Del Genio, A. D.: Effects of Cloud Parameterization on the Simulation of Climate Changes in the GISS GCM, J. Climate, 12, 761-779, doi:10.1175/15200442(1999)012<0761:EOCPOT>2.0.CO;2, 1999.

Yoon, Y. J., Ceburnis, D., Cavalli, F., Jourdan, O., Putaud, J. P., Facchini, M. C., Decesari, S., Fuzzi, S., Sellegri, K., Jennings, S. G., and O'Dowd, C. D.: Seasonal characteristics of the physicochemical properties of North Atlantic marine atmospheric aerosols, J. Geophys. Res.-Atmos., 112, D04206, doi:10.1029/2005jd007044, 2007.

Zhang, Q., Alfarra, M. R., Worsnop, D. R., Allan, J. D., Coe, H., Canagaratna, M. R., and Jimenez, J. L.: Deconvolution and Quantification of Hydrocarbon-like and Oxygenated Organic Aerosols Based on Aerosol Mass Spectrometry, Environ. Sci. Technol., 39, 4938-4952, doi:10.1021/es0485681, 2005. 